\title{
Sustainable Urban Design in Singapore
}

\author{
Sindhu Suresh, Neetha S N, Reshmi Manikoth Kollarath
}

\begin{abstract}
More than half the world population lives in urbanized areas and urban areas are responsible for two thirds of the energy consumption. Sustainable urban design is crucial in order to achieve a sustainable future in the context of climate change, resource depletion and population pressures. Even as the rest of the world is struggling to achieve the various goals for sustainable development the country of Singapore contributes less than $0.2 \%$ of global greenhouse gas (GHG) emissions. Siemens' Asian Green City Index states that Singapore is Asia's greenest metropolis. It is ranked second in the World Economic Forum's Sustainable Competitiveness Index. The country has achieved considerable progress in various areas of sustainability especially in the areas of transportation, energy, building and housing, water and urban farming. Singapore has managed to harness the technological innovations of the twenty first century and apply it in the urban design process thus accomplishing sustainable urban design which not only enhances the environment but also enhances the life of its citizens.
\end{abstract}

Keywords - Sustainability, urban design, transportation, energy, housing, water management

\section{INTRODUCTION}

Singapore has managed to make huge strides in sustainable urban design due to political will, long term urban planning and wise investments. Both the HDB and PUB have contributed significantly in the process of sustainable urban design. In spite of limited land and other natural resources Singapore has clean air, flowing traffic, good infrastructure.

On the social side, HDB actually planned communities. New towns are subdivided into neighbourhoods, precincts and building blocks. Within each block there are community spaces such as void decks and segmented corridors. These social spaces nurture community cohesion and a sense of belonging. [1]

\section{BACKGROUND}

Singapore was established as a British trading station in 1819 due to its locational advantage to attract merchants throughout Asia, America and Middle East with a free trade policy. By 1832, Singapore became the centre for the government of the Straits Settlements. The trade between the East and West further expanded in 1869 by the advent of steamship due to the opening of the Suez Canal and Singapore gained more importance. Singapore continued to grow well into the 20th century until World War II, when the Freeport became the scene of the war's significant fighting. The end of World War II saw Singapore becoming

Revised Manuscript Received on July 10, 2019.

Sindhu Suresh, BMS College of Architecture, Bangalore, Karnataka. India. (E-mail: sindhusureshh@gmail.com)

Neetha S N, BMS College of Architecture, Bangalore, Karnataka, India. (E-mail: neetha.sn@ gmail.com)

Reshmi Manikoth Kollarath, BMS College of Architecture, Bangalore, Karnataka India. (E-mail: reshmimk@gmail.com) a Crown Colony, but the rise of nationalism put Singapore on the path of self-government in 1959. In 1963 Singapore formed a union with Malaya, but in 1965 Singapore became fully independent after leaving the Federation of Malaysia. With no natural resources, Facing severe unemployment and a housing crisis, in the late 1960s through the 1970s Singapore embarked on a modernization program that focused on establishing a manufacturing industry, developing large public housing estates and investing heavily on public education. The government encouraged industries based on building and repairing the development of the port itself and tourism. Singapore was still heavily reliant on importing and exporting Malaysian produce, to reduce the country's reliance on entrepôt trade, a major industrialization programme began.

[2]By the 1990s, with a highly developed free market economy, strong international trading links, Singapore became one of the world's most prosperous nations and the highest per capita gross domestic product in Asia outside Japan.

\section{SUSTAINABLE URBAN DESIGN \& ANALYTICAL RESULTS}

Singapore has made sustainable urban design as one of the key strategies for development. The shortage of land and other natural resources has been an overriding factor pushing Singapore to achieve sustainability goals.

Singapore has managed to achieve considerable success in this field due to a combination of political will, long term urban planning and wise investments. Singapore has achieved a lot of success in these key areas
A. Transportation
B. Energy
C. Building and Housing
D. Water

The considerable progress and innovation in these fields have enabled Singapore to make considerable progress towards achieving sustainability goals.

\section{A. Transportation}

Transport within Singapore is mainly land-based. Many parts of Singapore are accessible by road, including islands such as Sentosa and Jurong Island. The other major form of transportation within Singapore is rail: the Mass Rapid Transit which runs the length and width of Singapore, and the Light Rail Transit which runs within a few neighbourhoods. The main island of Singapore is connected to the other islands by ferryboat services. 
There are two bridges which link Singapore to Malaysia - the Causeway, and the Second Link. The Singapore Changi Airport is a major aviation hub for many airlines, and Singapore is a major transshipment port.

Public transport in Singapore covers a variety of transport modes such as bus, rail and taxi.

The Government of Singapore has emphasized the use of public transport over private transport. As per the June 2018 report by McKinsey, Singapore ranks number one in the world in overarching urban mobility ranking with high affordability for public transport compared to other world cities in the list and is placed second in public transport ranking. The distinctive feature of Singaporean public transport is efficiency-the country's Land Transport Authority (LTA) is now working on developing a system of predictive maintenance.[3]

Public transport in Singapore is highly affordable. The Singapore Government introduced 15 percent discount on adult fares for low-wage workers, free travel for children, and seven other concessions which has made public transport attractive for the city's residents. Singapore LTA uses modern technology and electronic services such as Citymapper, Google, Hugo, and Quantum Inventions, to develop new enhanced trip planners, which incorporate transfers into planning intermodal public transport routes. The country follows a deliberate car limiting policy, which includes relatively high costs of buying a new car (more than $\$ 74,000$ for a small SUV), the requirement for a special certificate from the government to start driving (up to $\$ 37,000)$ and a charge to drive to the city center. These measures have helped to reduce congestion in the city center and a well maintained flow of traffic at all times.

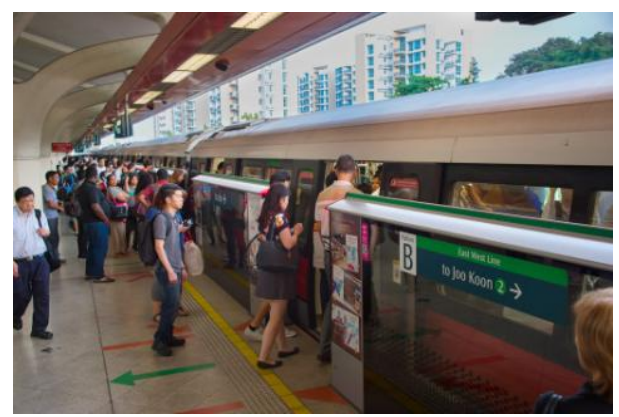

Fig 1. Mass Rapid Transit, Singapore.

Source: https://www.jllrealviews.com/places/asiapacific/singapore/can-singapores-public-transport-keepreal-estate-development/

\section{INTELLIGENT TRANSPORT SYSTEM}

Singapore's Land Transport Authority (LTA) uses the latest technology to improve traffic efficiency and safety. Intelligent Transport Systems (ITS), automate processes and collect data not just to improve traffic coordination and control, but also provide real-time traffic information to help users plan smoother journeys.

The Electronic Road Pricing (ERP) system deducts a charge from each vehicle's smart card device as it passes through a gantry which is adjusted according to demand, with higher rates during peak hours. The Green Link Determining (GLIDE) system improves traffic flow by adjusting the green time at traffic signals according to real- time vehicle and pedestrian volume. Wire sensors under the road surface detect vehicles, while push buttons on traffic signal poles inform the system of orphan.

Expressway Monitoring \& Advisory System (EMAS) have cameras along expressways to detect blockages and monitor speed. During breakdowns or accidents a recovery crew is alerted immediately and motorists are made aware of the situation through signboards along expressways. The ITS consolidates real-time data from other systems such as 400 surveillance cameras at major intersections-and TrafficScan-a network of GPS-enabled taxis that helps to investigate road conditions in the country. The information is disseminated and given to the public through electronic road signboards, radio broadcasts and put online. The traffic lights offer the elderly and pedestrians with disabilities longer crossing times. Traffic lights are also programmed to give priority to buses.

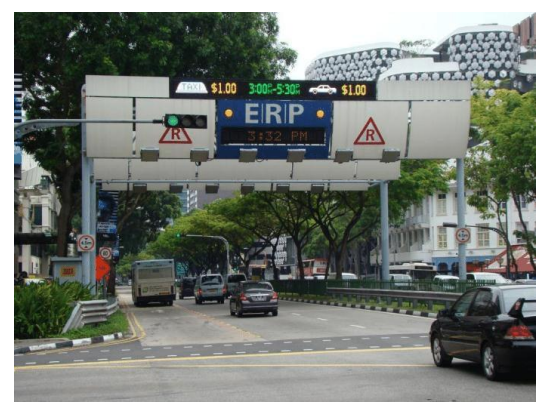

Fig 2. ERP Gantry at Victoria Gate. Source:researchgate.net

ITS has reduced road accident fatalities and decreased the clearing up time for accidents and shorter delays has led to annual cost savings of $\mathrm{S} \$ 40$ million. Today the traffic volume on expressways have come down to $15 \%$ and average travel speed has increased from 40 to $50 \mathrm{~km} / \mathrm{h}$. The city will soon have an ERP system which will charge motorists based on distance travelled on congested roads using satellites [4]

\section{SUSTAINABLE TRANSPORTATION}

Transportation is one of the main areas which is part of the 'Sustainable Singapore blueprint'. Singapore is trying to achieve sustainability in transportation through these three initiatives

i) Enhancing Public Transport

ii) Improving Resource Efficiency

- Managing Private Transport Usage :- This is achieved through controlling the growth rate of private vehicles through a combination of initiatives such as Electronic Road Pricing system and schemes that reduce car usage, such as the Off-Peak Car scheme and Park \& Ride scheme.

- Fuel Efficiency:-LTA has place d Green Framework for rail systems and Vehicular Emissions Scheme to control pollutants for other transport vehicles.

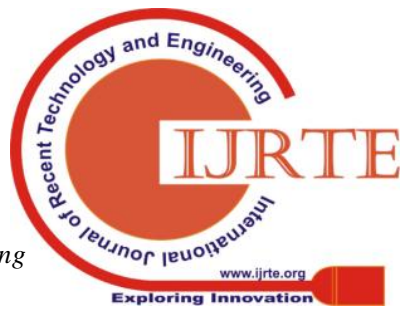


iii) Achieving Cleaner Transport

This is being achieved through measures such as

- Lowering carbon emission -

- Improving air quality: - Initiatives such as Easy Turnover Scheme to replace the more polluting diesel vehicles at discounted prices. The Government aims to decrease the quantity of fine particulate matter in the atmosphere.

- Encouraging greener forms of commuting: Infrastructure for biking and for pedestrians such as sheltered walkways, cycling paths and bicycle racks at MRT stations.

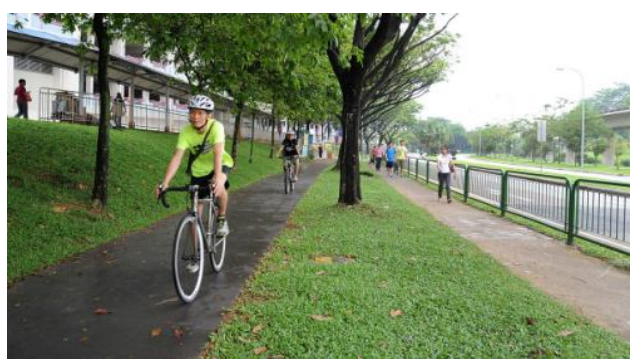

Fig 3. Biking and walking Infrastructure

Source: https://www.mot.gov.sg/About-MOT/Land-

Transport/Sustainable-Transport/Achieving-CleanerTransport/

\section{B.Energy}

These mitigation strategies from the perspective of reducing energy consumption that can be divided into three sub-categories.

1. Energy Consumption - ways of improving the energy efficiencies of various equipment used in residential, commercial and industrial sectors.

2. Building Systems - technical advancements that can be employed to improve energy savings.

3. Outdoor Systems - equipment used in outdoor spaces and the ways to decrease energy consumption through them.

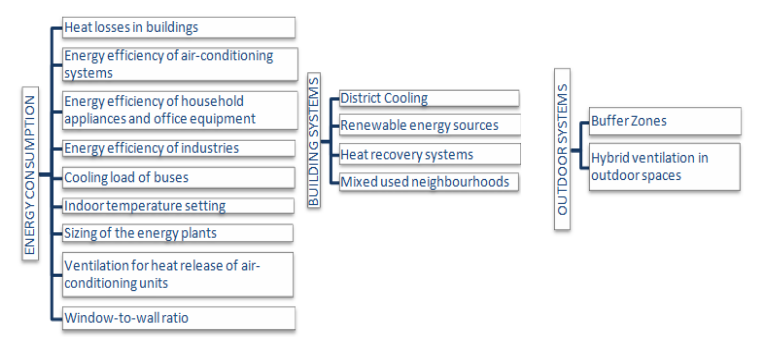

Figure 4. Energy Consumption Mitigation Strategies Source: Author

\section{ENERGY EFFICIENCY STRATEGIES IN SINGAPORE}

Generally the Cities are warmer than the rural areas that surround them. Cities consume huge amount of energy in electricity and fuel, have less vegetation to provide shade and cooling and the buildings are built of materials that absorb and store energy from the sun. This causes the phenomenon, known as the 'urban heat island' effect (UHI). This effect increases the temperature of the environment surrounding the urban buildings, which has an immediate effect on the energy consumption for cooling or heating these buildings depending on the season. In winter, when buildings need to be heated, the UHI effect decreases the energy consumed due to lower heating demands whereas in summer, the UHI effect increases the cooling demand for these buildings. Singapore has a tropical climate where the space cooling of building is a necessity throughout the year and therefore the UHI has a negative effect on the energy consumed. This in turn is also responsible for more intense storms, which sometimes lead to flooding. [5]

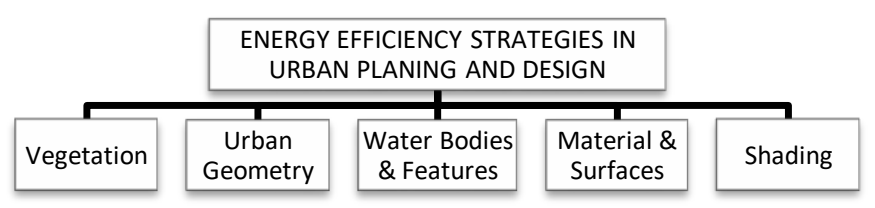

Figure 5. Energy Efficiency Strategies in Urban Planning and Design Source: Author

\section{VEGETATION}

As a mitigation strategy of 'urban heat island'(UHI) effect, Vegetation has extensively been used worldwide. High albedo and low heat admittance that have the effect of reducing accumulation of incoming solar energy in the urban area are the properties of vegetation. Additionally, to improve thermal comfort certain types of vegetation such as trees which can provide shade may be incorporated to reduce the heat gain from solar radiation. Also, the energy consumption for indoor cooling purpose can be reduced by the ambient air temperature reduction and building shading by vegetation.

Vegetation can be divided into three categories

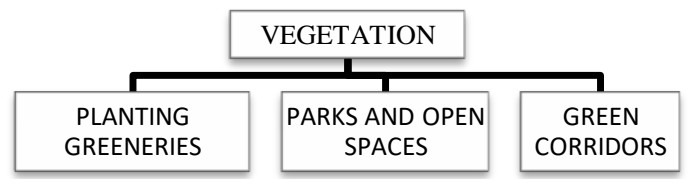

Figure 6. Vegetation Strategies Source: Author
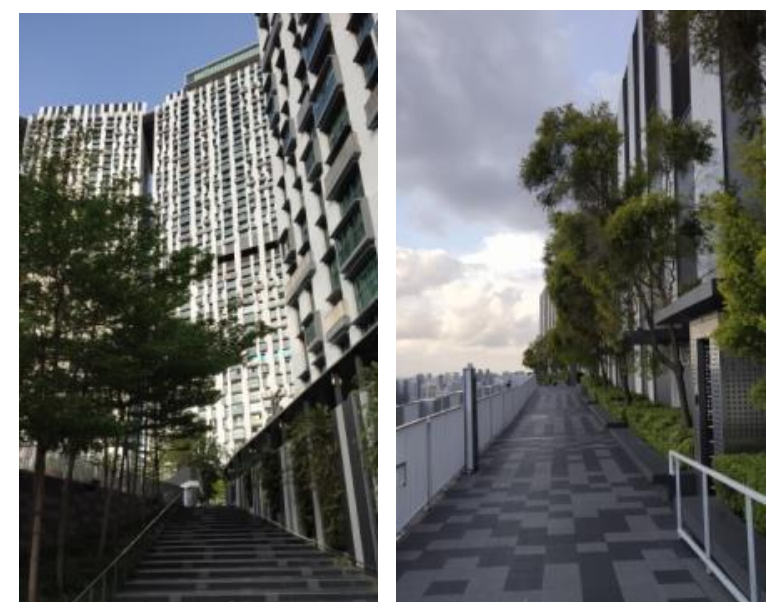

Figure 7. Pinnacle @ Duxton - Incorporating vegetation around the building. Source: Author

Blue Eyes Intelligence Engineering 


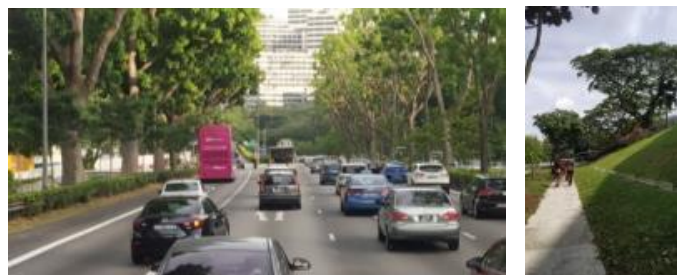

Fig 8 \& 9.Integrating green corridors in the entire city as a way of improving outdoor thermal comfort. Source: Author

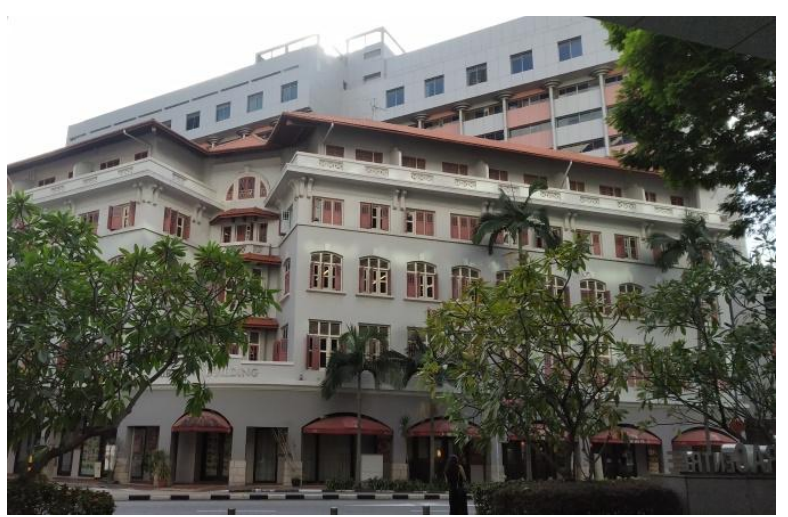

Fig 9. The relation between building and tree height will condition the amount of facade that is shaded by the trees and thus control the overheating of its surface.

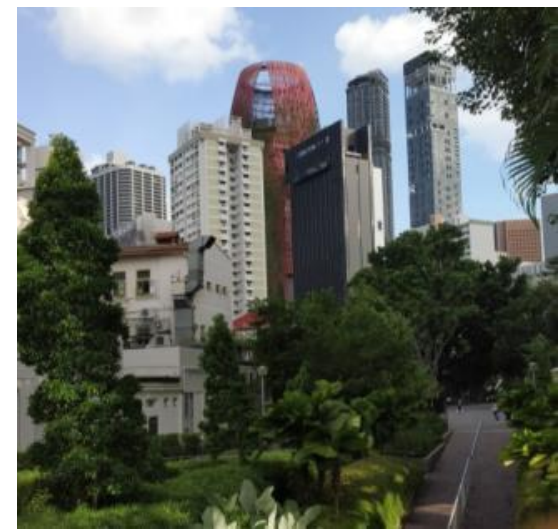

Fig 10.Parks and vegetation in Open Spaces improves the thermal performance of open spaces. Source: Author

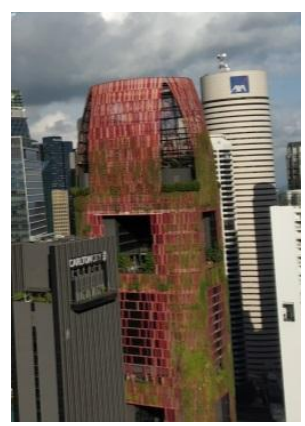

Fig 11.'living walls' or 'vertical gardens' or 'Green

Façades' can be considered as an alternative to insulating construction materials to reduce indoor overheating..

Source: Author

The arrangement of various elements such as the building layout, the location of urban elements, the building height and geometry are variables that condition the thermal performance of the urban area and affects the spatial coverage of the shadowed areas as well as the wind environment

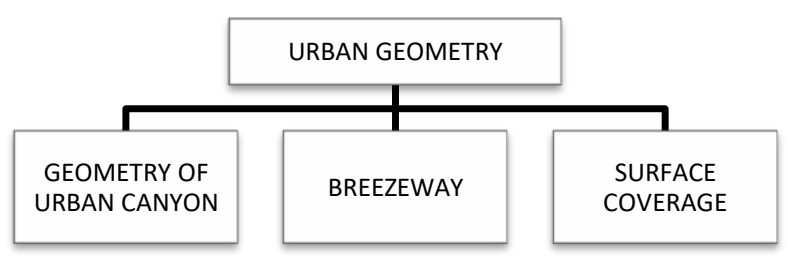

Fig 12.Integrating green corridors in the entire city as a way of improving outdoor thermal comfort. Source: Author

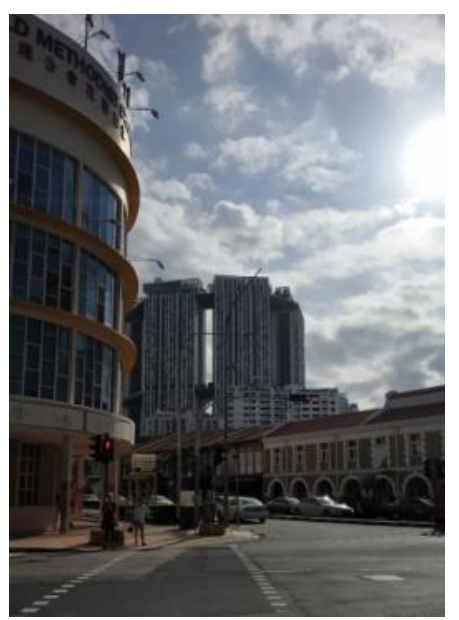

Fig 13. Different building heights and building forms can improve wind capture with benefits of Outdoor Thermal Cooling.

Source: Author

\section{WATER BODIES \& FEATURES}

To improve the overheating of building environments to some extent Water bodies and features may be incorporated as countermeasures. The effect of water is related to its surface temperature, which does not increase as much asthe rest of the urban area. Thus, it can be considered as a cool sink. Ponds are an accumulation of water that prevent the overheating of urban surfaces. They can be located on ground floor areas or on building roofs.

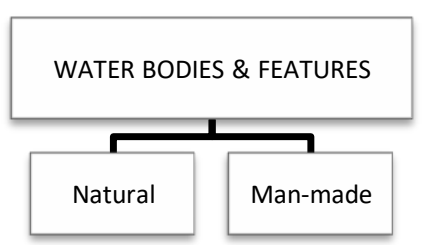

Fig 14. Types of water bodies Source: Author 

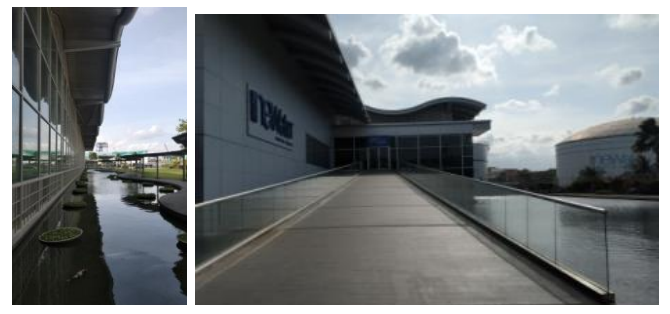

Fig15 :NEWater - Ponds in are an accumulation of water that prevent the overheating of urban surfaces. Theycan be located on ground floor areas or on building roofs Source: Author

\section{MATERIALS \& SURFACES}

The Urban climate and thermal balance of a city may be affected by the change in urban surface and materials. Cool pavements could be obtained by implementing lighter coloured asphalt on streets and roads and also by the use of cool tiles or special coatings on urban pavements.

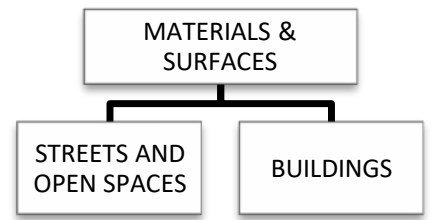

Fig16 :Types of Materials \& Surfaces as Energy Mitigants

Source: Author

\section{SHADING}

Shading leads to the reduction of air and surface temperature and can therefore result in cooling. It is relevant during daytime, especially around noon when the sun angles are at the highest.

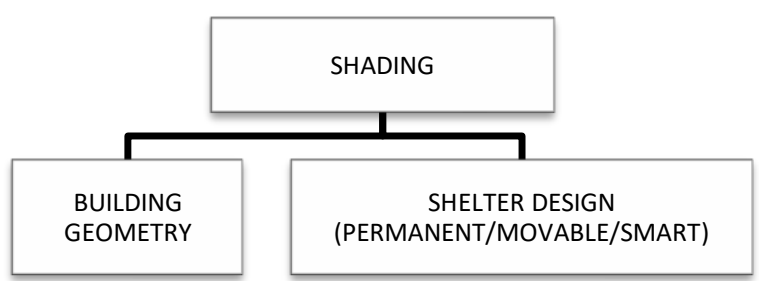

Fig17 :Ways of Shading. Source: Author
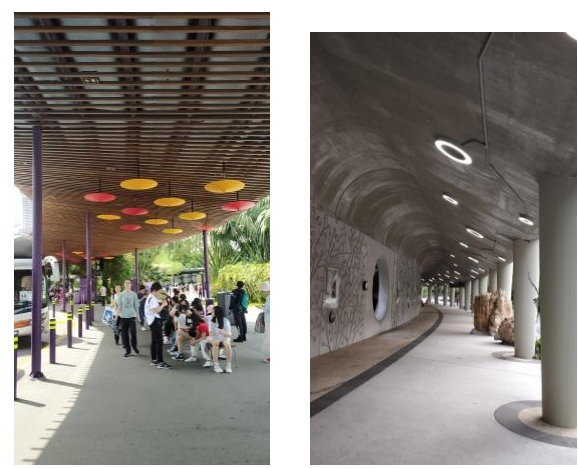

Fig 18 \& 19. Permanent shading devices such as solid and fixed structures that provide shade and protect people from harsh sunlight all day. Source: Author

\section{C.Building and Housing}

The Singapore is setting up a great example in the field of Green Buildings and sustainability. It is constantly evolving , inventing strategies for Sustainable Architecture and Green Buildings. The Climate change is real and Singapore's contribution to fight the climate change is substantial. Singapore wants to show the world that zero energy buildings can be built and it can be successful in all the ways. People come from all over the world to experience Green Singapore. Singapore has made it mandatory to practice sustainability in all the discipline like Urban Planning \& Design, Transportation, Housing, Tourism etc. It is mandatory in construction to make Green Buildings from 2008. That's the reason why Singaporeans are enjoying clean and pollution free environment till date.

To name few Green Buildings of Singapore- Marina Barage, The Pinnacle at Duxton, Net Zero Building at SDE,NUS etc.

1Marina Barrage dam, is a reservoir and it protects against flooding. This award-winning building is part of Marina Bay, a development created from land reclamation to relieve growth pressure on Singapore. The Green Roof is designed in such a way that it acts a Public Park where you get the excellent view of Singapore's Land Mark Buildings like Marina Bay Sands and Marina Gardens by The Bay etc. People come here for enjoying beautiful views, to fly kites and for Pre wedding Shoots. Marina Barrage has a Sustainable Gallery where all the sustainable measures taken by Singapore are illustrated in a way that every citizen and tourists understand the efforts and steps in making Singapore Sustainable.

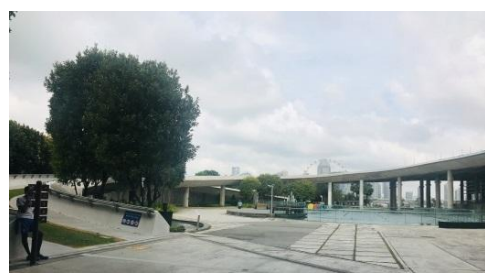

Fig 20. Marina Barage Sustainable Gallery, Singapore Source: Author

2. NUS has built one of its first Net Zero Energy Building at SDE. The design of this building is done in such a way that it consumes and recycles all the energy required for its functioning. The orientation of the building is designed to get maximum daylighting and afresh air throughout the day. Around 1200 photovoltaic panels help to generate the power which is required for the entire building.

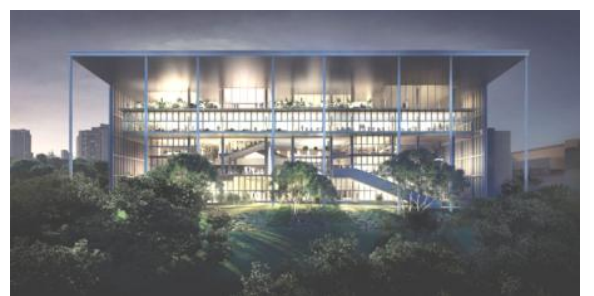

Figure 21. Net Zero Building at SDE, NUS Source: Author

3.The Pinnacle at Duxton: This is 50 floor residential 
complex at the city centre of Singapore developed by Housing \& Development Board(HDB) of Singapore. The unique feature of this building is the sky terrace connecting all the blocks at $52^{\text {nd }}$ storey. The sky bridge has jogging tracks and landscaped gardens which residents and tourists enjoy every day.

Climate Responsive Architecture: All the modern buildings were designed with respect to the local context and climate. The orientation and Façade treatments were as per the climatic condition of Singapore. Although many public buildings were air conditioned, due to the right orientation, energy consumption is reduced to a great extent.

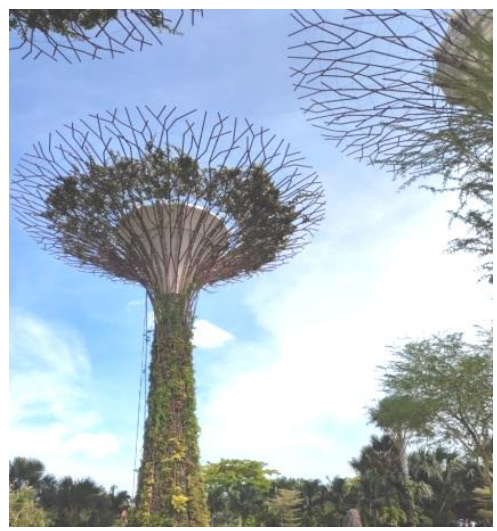

Figure 11. Super Trees of Singapore at Marina Gardens Source: Author

Super Trees of Singapore are the sustainable structures built to house solar panels which generate power to conduct light show every evening.

\section{Water}

\section{WATER STRATEGY IN SINGAPORE}

Singapore has made tremendous efforts since the 1980s to $1990 \mathrm{~s}$ to create a comprehensive environmental management system, including water supply, control of river pollution, establishment of well-planned industrial estates, and a world class urban sanitation system for the whole island. More recently, the Singapore government has made "sustainable water supply" the main target of water management, and a series of initiatives and actions have been undertaken. Singapore majorly relies on imports of water from Malaysia. To minimize its reliance on external sources, this city-state has developed and executed efficient demand and supply management practices.

Innovative integrated water management approaches such as the reuse of reclaimed water, the establishment of protected areas in urban rainwater catchments and the use of estuaries as freshwater reservoirs have been introduced along with seawater desalination.

The four water supply sources for Singapore:

1. Imported water from Malaysia

2. NEWater (recycled water)

3. Water desalination and

4. Local catchments (i.e. storm water runoff) and reservoirs.

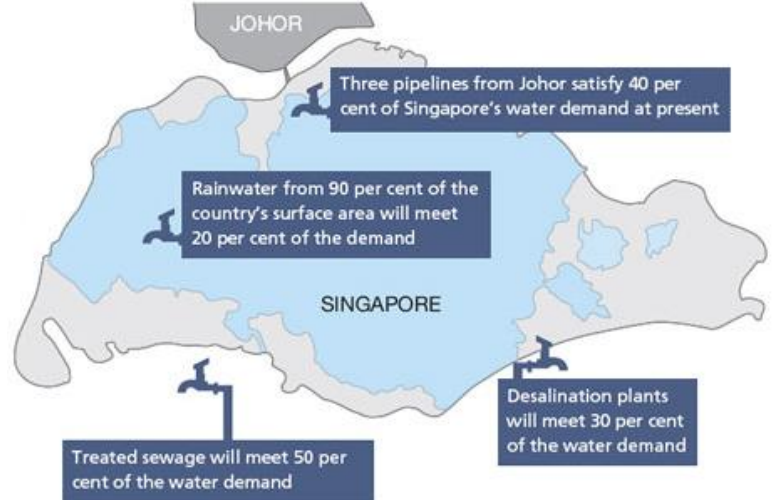

Fig 22: The Four Tap Strategies - showcases different ways of incorporated to make Singapore self-relient in water

Source: www.downearth.org

\section{Imported water from Malaysia}

Singapore imports 40 percent of its water from Malaysia under the 1962 Water Agreement, which is due to expire in 2061 and there is no guaranty of the renewal of the same. The rest of its supply comes from Newater, rainwater capture and desalination.

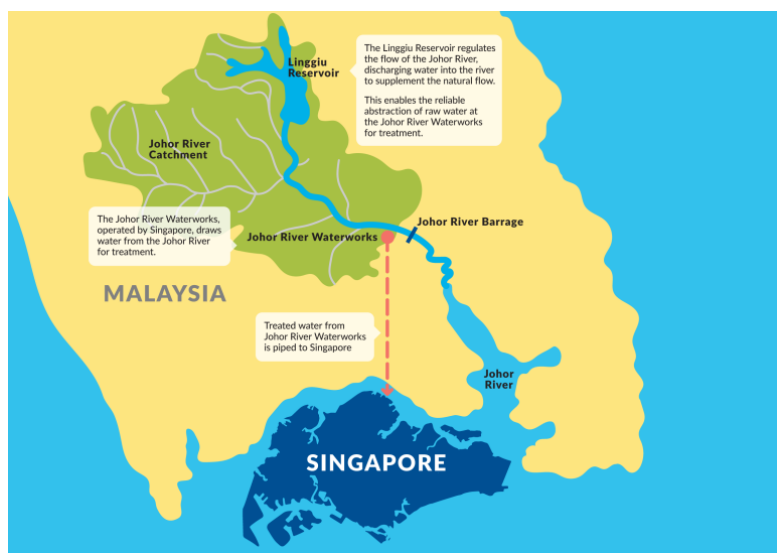

Fig 23: water from Malaysia through Linggiu Reservoir and Johor River Waterworks

Source: https://www.pub.gov.sg/

\section{NEWater (recycled water)}

Singapore's Public Utilities Board produces reclaimed water which is named as NEWater. It is wastewater (sewage) that has been treated and purified using dual-membrane (via microfiltration and reverse osmosis) and ultraviolet technologies, in addition to conventional water treatment processes. The NEWater plants supply up to $30 \%$ of Singapore's current water needs. By 2060, NEWater is expected to meet up to $55 \%$ of Singapore's future water demand. 


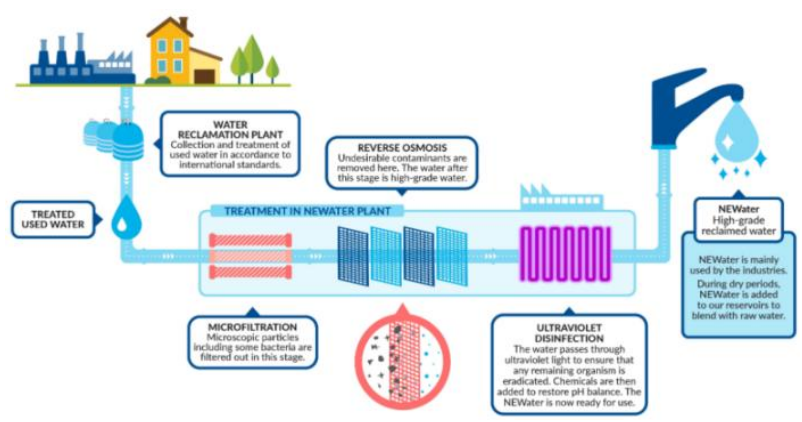

Fig 24: Water Treatment at NEWater Plant Source: www.pub.gov.sg

\section{Water Desalination}

In the 2000s, Singapore started developing desalinated water as an alternative source of fresh water supply under its long-term water supply diversification strategy. Desalinated water has now become Singapore's "fourth National Tap" meeting up to $25 \%$ of its water demand. [6]

Currently Singapore consists of two seawater desalination plants, namely the SingSpring Desalination Plant and the Tuaspring Desalination Plant.[7]

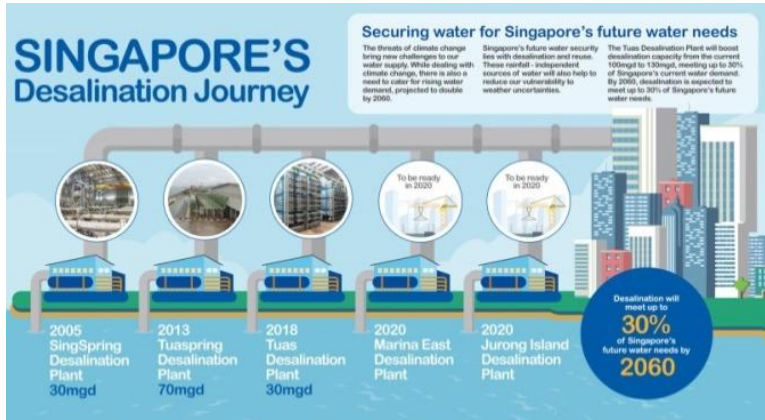

Fig 25: Water Desalination journey of Singapore Source: www.pub.gov.sg

\section{Water from Local catchment}

Two thirds of the Singapore's surface area is classified as partly protected catchment areas with certain restrictions on land use, so that the rainwater can be collected and used as drinking water. As of 2010, the water supply system included 19 raw water reservoirs, 9 treatment works and 17 service reservoirs for treated water. The largest reservoir, the Marina Bay reservoir inaugurated in 2008, is in the estuary of a river that has been closed off by a barrage to keep the seawater out. Two similar barrages were completed in 2011 and form the Punggol Reservoir and the Serangoon Reservoir. [8]

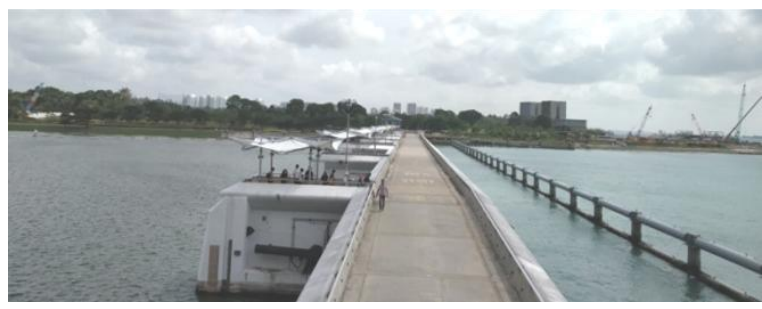

Fig 26: Marina Bay reservoir Source: Author

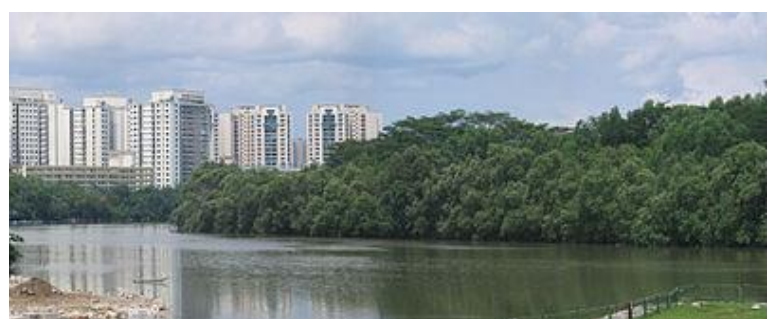

Fig 27: Sungei Serangoon,

with Rivervale neighbourhood of Sengkang New

Town on its west bank in the background. Source: https://en.wikipedia.org/wiki/Sungei_Serangoon

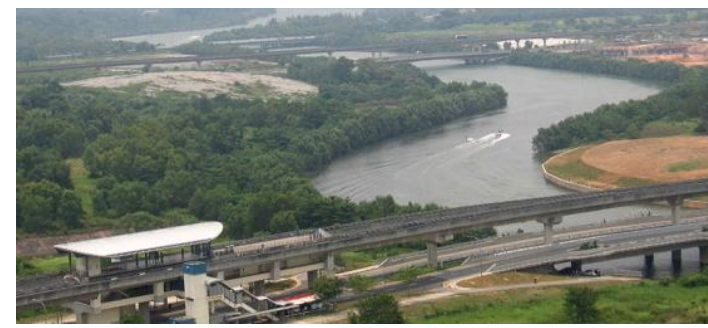

Fig 28: Sungei Punggol, flowing towards its mouth at the Straits of Johor.

Source:

https://en.wikipedia.org/wiki/File:Sungei_Punggol_4,_A ug_06.JPG

\section{ADDITIONAL WATER MANAGEMENT SYSTEMS}

\section{ROOFTOP WATER COLLECTION SYSTEMS}

1. Changi Airport: Changi Airport system collects and treats rainwater, which accounts for 28 to $33 \%$ of its total water used. These rooftops have higher potential as catchments.

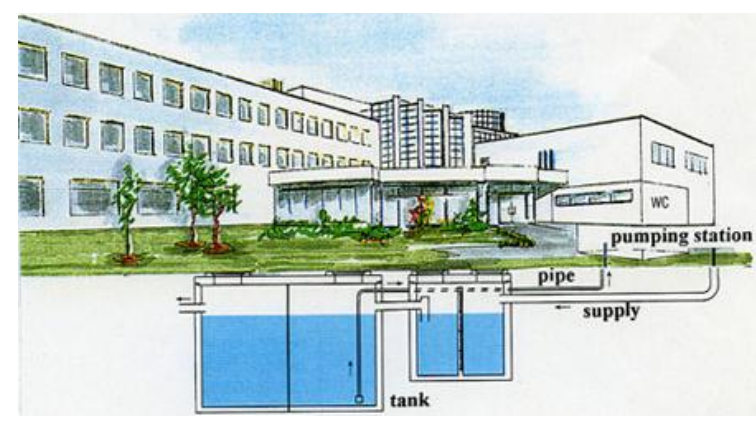

Fig 29: Rooftop water collection system at Changi Airport

Source: www.pub.gov.sg

2. High Rise Buildings: In a 15 storey building, this system is implemented. The roofwater collected was diverted to two rainwater tanks and the water was used only for flushing. The water quality was admissible in terms of color, turbidity and bacteriological content though the total solids and chloride levels were slightly higher. A simple dual mode system was incorporated in the collection tanks which were placed on the roof of the building. An economic appraisal established that there was an effective saving of $13.7 \%$ of the water. 


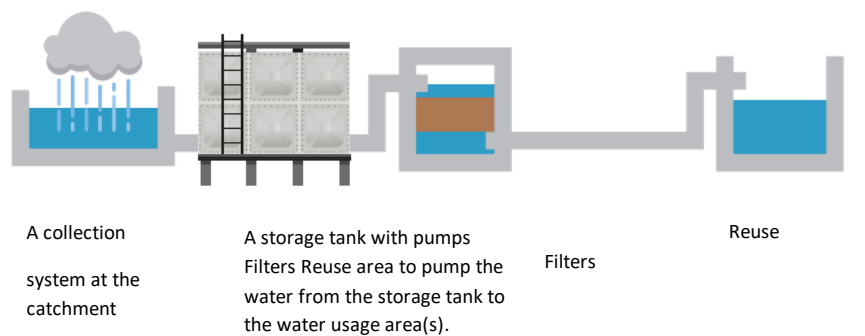

Fig 30: Rooftop water collection system in high rise buildings

Source: Practice guide in best water efficiency version 1 - PUB

\section{CAPTURING URBAN RUNOFF}

By 1986, the growing need for water led to the establishment of the lower Seletar-Bedok water scheme where almost nine percent of the total land area was used. The most important feature of this scheme is that almost one-quarter of this catchment is in urban area having high rise buildings and industries and surface run-offs were subject to a wide varities of contaminants. Hence the control of the water pollution and relevant technologies were the main priorities of the scheme. [9]

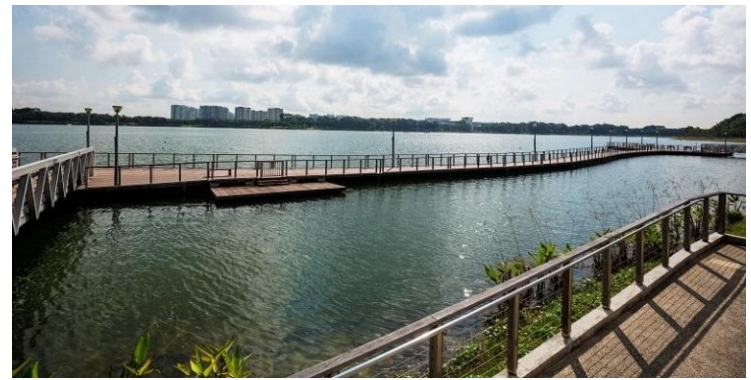

Fig 31: Bedok reservoir

Source: www.pub.gov.sg

\section{WATER AS PART OF URBAN DESIGN}

In 1989, an early effort was made to make the waterways more aesthetically pleasing.

The Ministry for National Development (MND) set up a multi-agency Water bodies Design Panel (WDP), with the objective to evaluate and advise on improvements to the designs and aesthetics of the major waterways so as to Sungei Punggol, Sungei Api Api and Alexandra Canal were implemented, with the intention to enhance the natural charm and beauty of their surroundings while retaining the core function of water drainage.[10]

Drainage reserve spaces have successfully been made into park connectors which are used by pedestrians and bicyclists. They are also made as a part of landscape element in the public spaces. Water and green spaces have been made a integral part of the built environment.

In 2002 URA and the National Parks Board launched a new Parks and Water bodies plan under Singapore Master Plan. The aim was to create a network of parks and provide easy accessibility to the waterways and water bodies for recreation. The park connectors increased accessibility to the water bodies and made them focal points of community activities. integrate them into the urban landscape. Projects such as

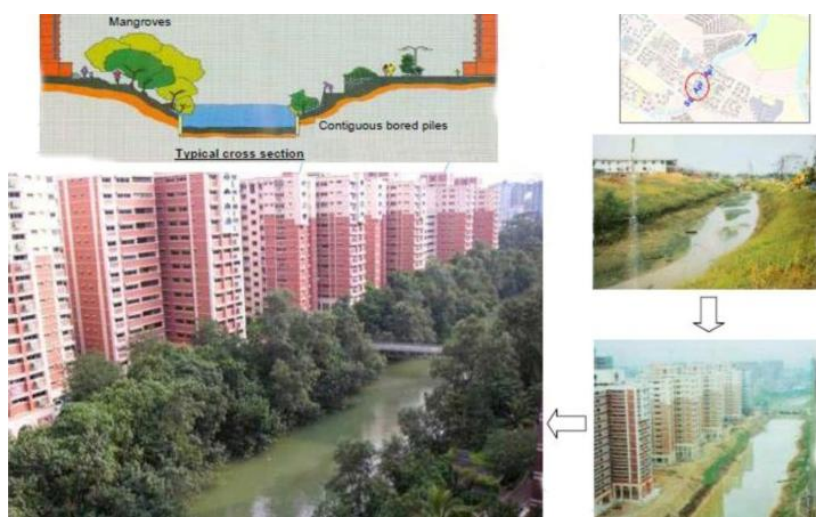

Fig 32: Cross-section and the location of the Sungei Api Api

Source: www.pub.gov.sg

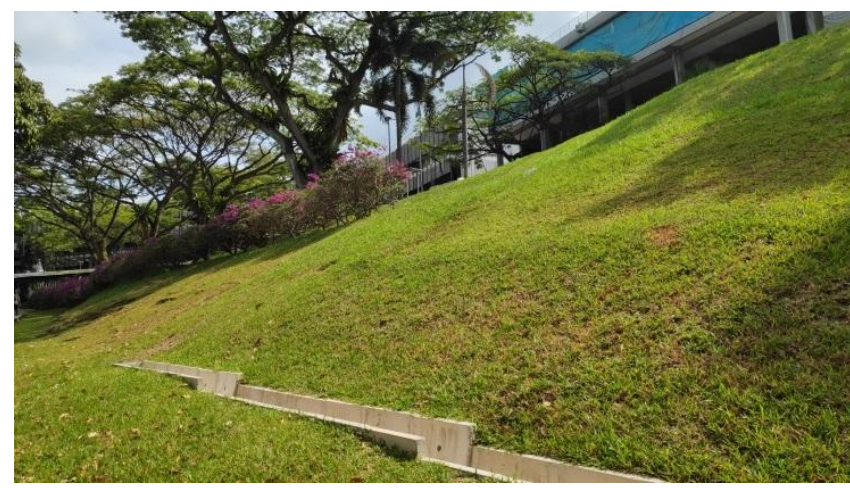

Fig 33: Storm water catchment areas integrated in the landscape along the built environment Source: Author

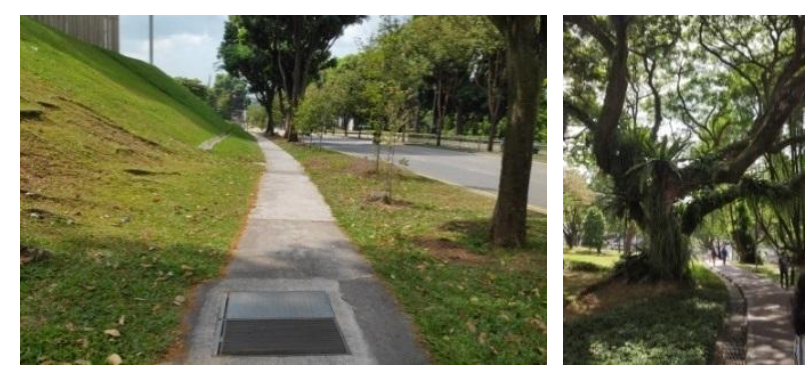

Fig 34: Drainage reserve spaces have successfully been made into park connectors

Source: Author

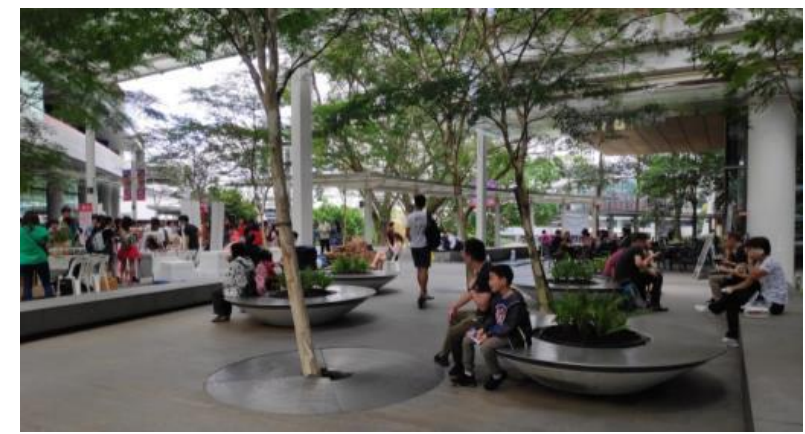

Fig 35: Rainwater collection integrated as a part of landscape in public spaces

Source: Author

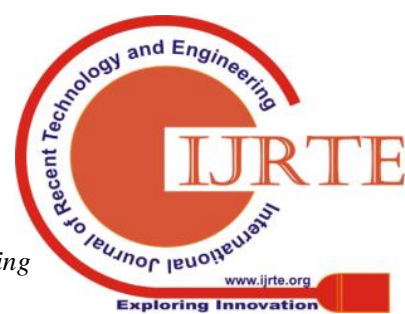




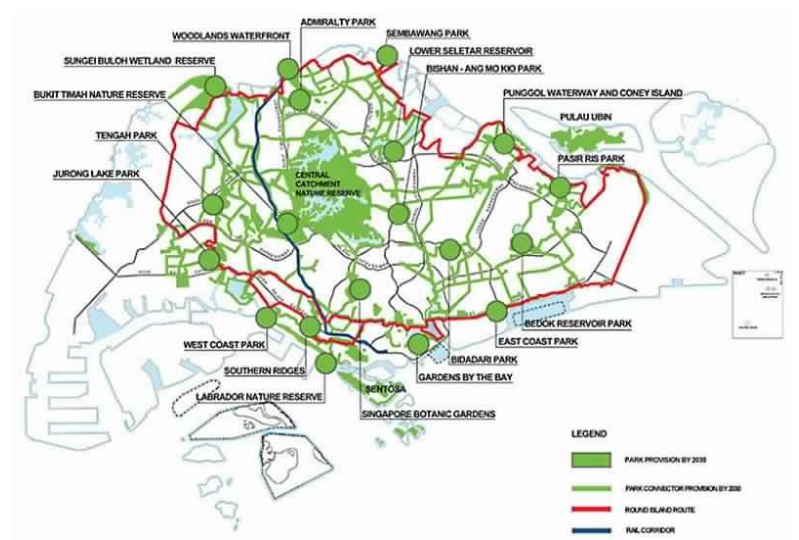

Fig 36: Park Connector, Singapore

Source:http://www.psst.ph/singapores-park-connectorhaven-bikers-runners/

\section{CONCLUSION}

Singapore has achieved considerable progress in terms of sustainable urban design due to its commitment towards the cause. The Singapore Government has displayed considerable political will to transform this island nation and make it a frontrunner in sustainability.

A combination of policy initiatives, incentives and legislations have helped in this transformation and the Government has been able to garner citizen participation which has become a major reason for the success of the Government undertakings. The various Government agencies including HDB, PUB, and LTA have led this campaign for sustainable future by harnessing latest technology to attain a greener and resilient nation.

The success of Singapore is a model which can be emulated by other countries. It also is a proof of how strong leadership and innovative Government initiatives can become the drivers towards sustainable urbanism which in turn brings about the wellbeing of its citizens.

\section{REFERENCES}

1. https://lkyspp.nus.edu.sg/gia/article/singapore-s-success-inurban-planning-learning-from-father-of-city-planning-dr-liuthai-ker

2. "World Economic Outlook Database". International Monetary Fund. September 2006.

3. McKinsey\&Company, "Elements of success: Urban transportation systems of 24 global cities", June 2018.

4. Tay Qiao Wei, "Tapping Tech for Smoother Traffic", Urban Solutions, Issue 13, July 2018, p 78-83

5. Lea A. Ruefenacht \& Juan A. Acero, 'Strategies for Cooling Singapore - A Catalogue of 80+ Strategies to Mitigate Urban Heat Island and Improve Outdoor Thermal Comfort'.

6. PUB Press Release (6 April 2011). "PUB and Hyflux sign Water Purchase Agreement for Singapore's second and largest desalination project"

7. "Desalinated Water". PUB, Singapore's National Water Agency.

8. www.pub.gov.sg

9. www.rainwaterharvesting.org

10. www.downearth.org 